\title{
Effects of Nitrogen, Phosphorus and Potassium Levels on Kenaf (Hibiscus cannabinus L.) Growth and Photosynthesis under Nutrient Solution
}

\author{
Md. Delwar Hossain (Corresponding author) \\ Institute of Tropical Agriculture, Universiti Putra Malaysia \\ 43400 Serdang, Selangor, Malaysia \\ Tel: 60-1-7666-5412Ｅ-mail: delwar200@yahoo.com \\ Mohamed Hanafi Musa \\ Department of Land Management, Faculty of Agriculture, \\ Universiti Putra Malaysia, 43400 Serdang, Selangor, Malaysia
}

Tel: 603-8946-6974Ｅ-mail:mmhanafi@agri.upm.edu.my

Jamal Talib

Department of Land Management, Faculty of Agriculture

Universiti Putra Malaysia, 43400 Serdang, Selangor, Malaysia

Tel: 603-8946-6972Ｅ-mail: jamal@agri.upm.edu.my

Hamdan Jol

Department of Land Management, Faculty of Agriculture

Universiti Putra Malaysia, 43400 Serdang, Selangor, Malaysia

Tel: 603-8946-6968_E-mail: hamdan@agri.upm.edu.my

The research is funded by Ministry of Higher Education (MOHE) top-down research grant, Malaysia.

\begin{abstract}
To date, little is known about the effect of levels of nitrogen, phosphorus and potassium on kenaf grown in nutrient solution culture. The objective of the present study was to examine the effects of different nitrogen, phosphorus and potassium levels on kenaf growth such as diameter, plant height, leaf number, root dry weight, stem dry weight and leaf dry weight and physiology like chlorophyll content, photosynthesis and stomatal conductance. Treatment consisted of 5 different levels of nitrogen viz. 0, 50, 100, 200 and $400 \mathrm{mg} / \mathrm{L}$ and 5 different levels of phosphorus and potassium viz. 0, 25, 50, 100 and $200 \mathrm{mg} / \mathrm{L}$ replicated thrice in a completely randomized design in a shade house. Growth (diameter, plant height and leaf number), chlorophyll content and photosynthesis were measured once weekly and plant components biomass was measured, 28 DAT. Different levels of nitrogen, phosphorus and potassium had significant effects on all the parameters studied. The highest values for diameter, plant height, leaf number, root dry weight, stem dry weight, leaf dry weight, photosynthesis and stomatal conductance were obtained from $200 \mathrm{~N}, 100 \mathrm{P}$ and $100 \mathrm{~K}$ whereas values decreased with further increase in levels of nutrient concentration. All the growth rates, chlorophyll content and photosynthesis declined with lower level of nitrogen, phosphorus and potassium. Among the plant components, leaf dry weight had the greatest decrease while root/shoot ratio increased under $\mathrm{N}$ deficiency. The results of this study provide new knowledge to produce kenaf with better nutrient management in the field.
\end{abstract}

Keywords: Kenaf, Growth, Chlorophyll content, Photosynthesis, Nutrition

\section{Introduction}

There has been an increase in interest in growing kenaf throughout the world for its high biomass yield and the elevated fibre content. Kenaf (Hibiscus cannabinus L.), a fast growing $\mathrm{C}_{3}$ plant native of tropical Africa, is being 
investigated as new source of bioenergy as well as an industrial crop and has high potential to be used in Malaysia. The high biomass yield and the elevated fibre content of kenaf justify the growing interest on this multipurpose crop for its potential role in agroecosystems involving biomass production as substitute of non-renewable resources (Cosentino and Copani, 2003).

Nitrogen, phosphorus, potassium and water are considered as the major limiting factors in crop growth, development and finally economic yield (Glass, 2003; Parry, et al., 2005). To grow kenaf the responses of plants to $\mathrm{N}, \mathrm{P}$ and $\mathrm{K}$ fertilization are of considerable importance in agriculture. Although $\mathrm{N}, \mathrm{P}$ and $\mathrm{K}$ frequently limits growth and development of several crop species under field conditions, the precise mechanisms by the limitation occurs are complex and variable depending on species, developmental stage and environment. Limited N, P and $\mathrm{K}$ supply decreases rates of cell division, cell expansion and cell permeability (Roggatz et al., 1999), photosynthesis, leaf production, and growth, plants (Chapin, 1980; Clarkson and Hanson, 1980; Evans, 1983; Radin and Boyer, 1982; Sinclair and Horie, 1989; Reddy et al., 1997a; Gerik et al., 1998; Zhao et al., 2003, 2005a, b) and yield (Zhao et al., 2007). Some reports suggest that $\mathrm{N}$ deficiency affects more strongly the leaf development than photosynthesis (Watson, 1952; Wong, 1979; Radin and Boyer, 1982; Reddy et al., 1997a). Field and Mooney (1986) and Gerik et al. (1998) in their reviews described many of the responses of plants to N, $\mathrm{P}$ and $\mathrm{K}$ deficiency. They described the effects of low N, P and $\mathrm{K}$ nutrition on plants as causing lower photosynthetic rates and slower leaf expansion. Muchow (2009) reported that photosynthetic capacity of keanf increased with specific leaf nitrogen from o to $24 \mathrm{~g} \mathrm{~N} \mathrm{~m}^{-2}$.

For better fertilizer management the study about the effects of different levels of N, P and $\mathrm{K}$ on the kenaf growth and photosynthesis is very crucial. We hypothesize that critical N, P and $\mathrm{K}$ levels vary depending on growth and physiological processes, and growth and physiological processes differ in their responses to different levels of $\mathrm{N}$, $\mathrm{P}$ and $\mathrm{K}$. The objectives of this study were to investigate the effects of $\mathrm{N}, \mathrm{P}$ and $\mathrm{K}$ on kenaf plant growth and physiology in nutrient solution culture to find out optimum levels of $\mathrm{N}, \mathrm{P}$ and $\mathrm{K}$ for nutrient management practices of kenaf, and to derive functional relationship between $\mathrm{N}, \mathrm{P}$ and $\mathrm{K}$ levels and different growth and physiological processes.

\section{Materials and methods}

\subsection{Site description and plant materials}

An experiment was conducted at the Experimental Farm No. 2, Universiti Putra Malaysia, Serdang, Selangor, Malaysia $\left(2^{\circ} 59^{\prime} 20.56^{\prime \prime} \mathrm{N}, 101^{\circ} 42^{\prime} 44.42^{\prime \prime} \mathrm{E}\right)$ under a shade house for a period of 28 days (since 12June to 10 July 2009). The photosynthetically active radiation (PAR) during the growing period was $500-700 \mu \mathrm{mol} \mathrm{m}^{-2} \mathrm{~s}^{-1}$. Cultivar V36 of kenaf was used in this experiment as plant material.

\subsection{Seedling growth}

The kenaf seeds were sown directly on sand beds for germination. After 10 days, seedlings with similar size of plumule and radicle were selected for placing into the polypropylene tray containing Hoagland's nutrient solution (Hoagland and Arnon, 1950).

\subsection{Treatments}

The seedlings were placed into a polypropylene tray containing 20L of aerated Hoagland's nutrient solution. The following treatments were imposed: (1) five levels of $\mathrm{N}-0,50,100,200$ and $400 \mathrm{mg} / \mathrm{L}$ and (2) five levels of $\mathrm{P}$ and $\mathrm{K}-0,25,50,100$ and $200 \mathrm{mg} / \mathrm{L}$. Each treatment was divided into three replications of 10 plants per replication. The Hoagland's nutrient solution was modified substituting $\mathrm{CaCal}_{2}$ for $\mathrm{Ca}\left(\mathrm{NO}_{3}\right)_{2}$ to allow the different $\mathrm{N}$ concentration (Reddy et al., 1996). It was also modified to obtain the different levels of $\mathrm{P}$ and $\mathrm{K}$ as required by the treatments. The nutrient solution was renewed every 7 days. All the plants were harvested 28 days after transplanting (DAT) in the nutrient solution.

\subsection{Growth measurements}

Plant height, diameter and leaf numbers were determined on five plants in each replication at 7-day intervals throughout experimental period. Stem lengths were measured as the distance between cotyledon level and the stem apex. Measurement of collar diameter was made using a digital caliper. Leaf number was counted when the main veins were first visible.

Biomass was collected from the plants under all the treatments at the end of the experiment. Roots, stems and leaves were separated and dried at $70^{\circ} \mathrm{C}$ in an electric oven for 48 hours to constant weight to estimate plant components dry weights. From these measurements, partitioning to above and below ground parts along with root to shoot ratios was calculated. 


\subsection{Physiological measurements}

During treatment period (28 DAT), chlorophyll content of the third fully expanded leaf from the top was measured using a portable chlorophyll meter (Minolta SPAD-502, Japan) from 8:00 to 11:00 h at 7-day intervals. Net photosynthesis rates and stomatal conductance of the uppermost, expanded main stem leaves, which were the third from main axis terminal, from five plants in each treatment were measured between 8:00 and 11:00 h using an open gas exchange system, LI-6400 portable photosynthesis system (LiCOR Inc., Lincoln, Nebraska, USA).

\subsection{Data analysis}

Growth measurements such as diameter, plant height, leaf numbers, spad value and photosynthesis rates and stomatal conductance were averaged over the replications for all measuring dates and their means were used in deriving relationships between growth and physiological parameters. The differences in growth and physiology between the N, P and K treatments were calculated by using the SAS statistical procedure PROC. ANOVA and Duncan's Multiple Range Test (DMRT) at $\mathrm{p}<0.05$ (SAS Institute Inc., 2007). Correlation test with significance level reported $(\mathrm{p}<0.05$ or $\mathrm{p}<0.01)$ was based on Pearson's correlation coefficient.

\section{Results and discussion}

The strategy of growing kenaf plants until 28 days of placement in Hoagland's nutrient solution and imposing various $\mathrm{N}, \mathrm{P}$ and $\mathrm{K}$ treatments worked well for the purpose of achieving variability in plant growth and physiological parameters and to derive functional relationships between various processes and $\mathrm{N}, \mathrm{P}$ and $\mathrm{K}$ levels. Biomass accumulated measured at 28 DAT was very sensitive to $\mathrm{N}, \mathrm{P}$ and $\mathrm{K}$ treatments and plants grown under $\mathrm{N}, \mathrm{P}$ and $\mathrm{K}$ deprivation showed significantly $(\mathrm{p}<0.05)$ lower total biomass as well as all plant components dry weights (Table 1-3) similar to earlier findings (Zhao et al., 2005a, b; Sinclair, 1990). Total plant biomass accumulated was less by $97 \%, 92 \%$ and $77 \%$, respectively for the $0 \mathrm{~N}, 0 \mathrm{P}$ and $0 \mathrm{~K}$ treatments. Of all the plant dry weight components, leaf weight was lower by $98 \%, 94 \%$ and $87 \%$ for the plants under $0 \mathrm{~N}, 0 \mathrm{P}$ and $0 \mathrm{~K}$ treatments, respectively $(\mathrm{p}<0.05)$, compared to the $200 \mathrm{~N}, 100 \mathrm{P}$ and $100 \mathrm{~K}$ treatments (Table1-3). Therefore, N, P and K affected several processes in kenaf plant that ultimately led to lower the biomass production. The biomass production in root, stem and leaf increased up to $200 \mathrm{~N}, 100 \mathrm{P}$ and $100 \mathrm{~K}$ treatments and then declined. This might be due imbalanced nutrient concentration or toxicity caused by the higher nutrient concentration.

Diameter and plant height during the experimental period showed significant differences among the treatments with regards to the level of nutrient concentrations. Plant height extension that includes all growing internodes, expansion of all leaves and effective PAR capture and interception (Alm et al., 1991; Morrison et al., 1994; Reddy et al., 1997b) will affect overall canopy development (Reddy et al., 1997a, 2004; Gerik et al., 1998). During the 28 days of treatment, there were significant differences in stem lengths due to N, P and K treatments (Table 1-3). Plants in the $200 \mathrm{~N}, 100 \mathrm{P}$ and $100 \mathrm{~K}$ were taller than the other treatments on all measured dates and at higher nutrient concentrations after that plant height decreased. Plants grown in $200 \mathrm{~N}, 100 \mathrm{P}$ and $100 \mathrm{~K}$ treatments were $76 \%, 64 \%$ and $58 \%$ taller than the plants grown in the $0 \mathrm{~N}, 0 \mathrm{P}$ and $0 \mathrm{~K}$ treatments, respectively (Table 1-3). Shorter plants under N, P and K deficiency might have been due to their effects on cell elongation as well as cell division (Roggatz et al., 1999).

Leaf number was significantly different for every level of nutrient concentration. Leaf numbers increased in all treatments over time up to $200 \mathrm{~N}, 100 \mathrm{P}$ and $100 \mathrm{~K}$. Fewer numbers of leaves produced under deficient N, P and K conditions might be due to their indirect effect since node addition rates are primarily controlled by temperature and modulated carbon demand/supply (Reddy et al., 1997a, 2004). Decreased net photosynthesis under N, P and $\mathrm{K}$ deficient conditions observed in this study would result in lower carbon supply which will result in fewer leaves per plant in N, P and K stressed kenaf plants.

Leaf chlorophyll content was significantly influenced by the levels of $\mathrm{N}, \mathrm{P}$ and $\mathrm{K}$ and declined in $0 \mathrm{~N}, 0 \mathrm{P}$ and $\mathrm{OK}$ treatments during the treatment period due to growth. The chlorophyll content of the leaf was negatively correlated with the age of the plants during the treatment period at 0 levels of N, P and K. (Fig.1-3).

Photosynthesis was significantly increased with the increase of nutrient concentration up to $200 \mathrm{~N}, 100 \mathrm{P}$ and $100 \mathrm{~K}$ and afterwards, decreased (Fig. 4-6). Photosynthesis of $200 \mathrm{~N}, 100 \mathrm{P}$ and $100 \mathrm{~K}$ were $14.45 \mu \mathrm{mol} \mathrm{m}^{-2} \mathrm{~s}^{-1}$, $12.56 \mu \mathrm{mol} \mathrm{m} \mathrm{m}^{-1}$ and $12.83 \mu \mathrm{mol} \mathrm{m} \mathrm{s}^{-1}$, respectively, when averaged across the measuring times. The lowest photosynthesis was observed in $0 \mathrm{~N}, 0 \mathrm{P}$ and $0 \mathrm{~K}$ treatments. This finding is in agreement with Reddy and Matcha (2009). They found much steeper declining photosynthesis in $0 \mathrm{~N}$ compared to the $100 \mathrm{~N}$ in other crop experiment. Similar to leaf photosynthesis, stomatal conductance declined with lower N, P and K levels (Fig. 7-9); the decline however, was slightly less responsive with $\mathrm{N}, \mathrm{P}$ and $\mathrm{K}$ levels. Since internal carbon dioxide 
concentration did not show any significant differences among N, P and $\mathrm{K}$ treatments over time except at very low N, P and K levels in the 0N, OP and 0K treatments (data not shown; Schulze, 1986), the decline photosynthesis at low $\mathrm{N}, \mathrm{P}$ and $\mathrm{K}$ levels might be due to both greater stomatal resistance and the less biochemical efficiency of chloroplasts (Chapin, 1980; Reddy et al., 1696).

\section{Conclusion}

Our results show that kenaf plant growth such as diameter, stem elongation and leaf number are positively correlated with N, P and K levels until a certain level. In addition, N, P and K deficiency decreased plant height and photosynthesis of kenaf plants leading to lower biomass accumulation. Maximum growth and photosynthesis rates were achieved at $200 \mathrm{~N}, 100 \mathrm{P}$ and $100 \mathrm{~K}$. Among the plant components, leaf dry weight had the greatest decrease under $\mathrm{N}, \mathrm{P}$ and $\mathrm{K}$ deficiency while root/shoot ratio increased under $\mathrm{N}$ deficiency. Furthermore, the functional relationships between N, P and K level and growth and physiological processes might be useful to develop better nutrient management practices of kenaf plants that typically encounter under field conditions.

\section{Acknowledgements}

This research was funded by the Ministry of Higher Education (MOHE) top-down research grant. We also thank to Mr. Baharoom Zainal for providing seed and Jose Alvaro Cristancho Rodriguez for his comments and suggestions about hydroponic management.

\section{References}

Alm, D.M., McGriffen Jr., M.E. and Hesketh, J.D. (1991). Weed phenology, In: Hodges, T. (Ed.), Predicting Crop Phenology CRC Press. Boca Raton, Fl., pp. 191-218.

Chapin III, F.S. (1980). The mineral nutrition of wild plants. Annu. Rev. Ecol. Syst. I, 233-260.

Clarkson, D.T and Hanson. (1980). The mineral nutrition of higher plants. Annu. Rev. Plant Physiol., 31, 239-298.

Cosentino, S.L. and Copani, V. (2003). Agroindustria, 2,2/2: 137-145.

Evans, J.R. (1983). Nitrogen and photosynthesis in the flag leaf of wheat (Triticum eastivum L.). Plant Physiol., 72, 297-302.

Field, C. and Mooney, H.A. (1986). The photosynthesis-nitrogen relationships in wild plants. In: Givinish, T.J. (Ed.), On the Economy of Form and Function Cambridge University Press, Cambridge, England, pp. 25-55.

Gerik, T.J. Oosterhuis D.M. and Torbert, H. A. (1998). Managing cotton nitrogen supply Adv. Agron. 64, 115-147.

Glass, A.D.M. (2003). Nitrogen use efficiency of crop plants: physiological constraints upon nitrogen absorption. Crit. Rev. Plant Sci., 22, 453-470.

Gruissem, W., Jones, R.I., (Eds.), Biochemistry and Molecular Biology of Plants. American Society of Plant Physiologists, Rockville, pp. 1158-1203.

Hoagland, D and Arnon, D. (1950). The water culture method for growing plants without soil. Californian Agricultural Station. p347.

Morrison, T.A., Kessler, J.R. and Buxton, D.R. (1994). Maize internode elongation patterns. Crop Sci., 34, 1055-1060.

Muchow, R.C. (2009). Effect of leaf nitrogen and water regime on the photosynthetic capacity of kenaf (Hibiscus cannabinus L.) under field conditions. Australian Journal of Agricultural Research, 41(5) 845 - 852.

Parry, M.A.J., Flexas, J. and Medrano, H. (2005). Prospects for crop production under drought: research priorities and future directions. Ann. Appl. Biol., 147, 211-226.

Radin, J.W. and Boer, J.S. (1982). Control leaf expansion by nitrogen nutrition in sunflower plants: role of hydraulic conductivity and turgor. Plant Physiol., 69, 771-775.

Reddy, A.R., Reddy, K.R., Padjung, R., and Hodges, H.F. (1996). Nitrogen nutrition and photosynthesis in the leaves of pima cotton J. Plant Nutr., 19, 755-790.

Reddy, K.R. and Matcha, S.K. (2009). Quantifying nitrogen effects on castor bean (Ricinus communis L.) development, growth, and photosynthesis. Ind. Crops Prod. Doi: 10. 1016/i. indcrop. 2009. 10.004. 
Reddy, K.R., Hodges, H.F. and McKinion, J.M. (1997a). Crop modeling and applications: a cotton example Adv. Agron. 59, 225-290.

Reddy, K.R., Hodges, H.F. and McKinion, J.M. (1997b). Modeling temperature effects on cotton internode and leaf growth. Crop Sci., 37, 503-509.

Reddy, K.R., Koti, S., Davidonis, D. and Reddy, V.R. (2004). Effects of carbon dioxide enrichment and nitrogen nutrition on nutrient concentration, yield and fiber quality of cotton. Agron. J., 96, 1139-1147.

Roggatz, U., Mcdonald A.J.S. Stadenberg, I. and Schurr, U. (1999). Effects of nitrogen deprivation on cell division and expansion in leaves of Ricinus communis L. Plant Cell Environ., 22, 81-89.

SAS Institute Inc. (2007). SAS/STAT User's Guide, Version 9.2. SAS Institute Inc., Cary, NC, USA.

Sculze, E.D. (1986). Carbon dioxide and water vapor exchange in response to drought in the atmosphere and in the soil. Annu. Rev. Plant Physiol., 37, 247-274.

Sinclair, T.R. (1990). Nitrogen influence on the physiology of crop yield. In: Rabbinage, R. Goudriaan, J., van Keulen, H., Penning de Vries, F.W.T., van Laar, H.H. (Eds.), Theoretical Production Ecology: Reflections and Prospects. Pudoc. Wagerningen, Netherlands, pp. 41-45.

Watson, D.J. (1952). The physiological basis of variation in yield. Adv. Agron., 4, 101-145.

Wong, S.C. (1979). Elevated atmospheric partial pressure of $\mathrm{CO} 2$ and plant growth. Interactions of nitrogen nutrition and photosynthetic capacity in C3 and C4 plants Oecologia (Berlin) 44, 68-74.

Zhao, D., Reddy, K.R., Kakani, V.G., Read, J.J. and Carter, G.A. (2003). Corn (Zea mays L.) growth leaf pigment concentration, photosynthesis and leaf hyperspectral reflectance properties as affected my nitrogen supply. Plant Soil, 257, 205-217.

Zhao, D., Reddy, K.R., Kakani, V.G., Read, J.J. and Koti, S. (2005a). Selection of optimum reflectance ratios for estimating leaf nitrogen and chlorophyll concentrations of field-grown cotton. Agron. J., 97. 89-98.

Zhao, D., Reddy, K.R., Kakani, V.G., Read, J.J. and Koti, S. (2005b). Nitrogen deficiency effects on plant growth, leaf photosynthesis, and hyperspectral reflectance properties of sorghum. Eur. J. Agron., 22, 391-403.

Zhao, D., Reddy, K.R., Kakani, V.G., Read, J.J. and Koti, S. (2007). Canopy reflectance in cotton for growth assessment and prediction of lint yield. Eur.J. Agron., 26, 335-344.

Table 1. Influence of nitrogen nutrition levels on kenaf plant growth and dry weights of different plant parts

\begin{tabular}{llllll}
\hline \multirow{2}{*}{ Parameters } & \multicolumn{5}{c}{ Nitrogen treatment $(\mathrm{mg} / \mathrm{L})$} \\
\cline { 2 - 6 } & 0 & 50 & 100 & 200 & 400 \\
\hline Diameter, mm & $2.57 \mathrm{~d}$ & $5.73 \mathrm{c}$ & $7.58 \mathrm{~b}$ & $8.71 \mathrm{a}$ & $7.51 \mathrm{~b}$ \\
Plant height, cm & $13.33 \mathrm{c}$ & $44.67 \mathrm{~b}$ & $48.06 \mathrm{~b}$ & $55.48 \mathrm{a}$ & $47.30 \mathrm{~b}$ \\
Leaf number, plant $^{-1}$ & $4.33 \mathrm{~d}$ & $10.33 \mathrm{c}$ & $11.33 \mathrm{c}$ & $16.67 \mathrm{a}$ & $14.00 \mathrm{~b}$ \\
Root dry weight, g plant $^{-1}$ & $0.04 \mathrm{c}$ & $0.45 \mathrm{~b}$ & $0.49 \mathrm{~b}$ & $0.64 \mathrm{a}$ & $0.50 \mathrm{~b}$ \\
Stem dry weight, g plant $^{-1}$ & $0.04 \mathrm{~d}$ & $0.64 \mathrm{c}$ & $1.07 \mathrm{~b}$ & $1.33 \mathrm{a}$ & $0.97 \mathrm{bc}$ \\
Leaf dry weight, g plant $^{-1}$ & $0.02 \mathrm{c}$ & $0.49 \mathrm{~b}$ & $0.52 \mathrm{~b}$ & $1.07 \mathrm{a}$ & $0.82 \mathrm{ab}$ \\
Total dry weight, g plant $^{-1}$ & $0.10 \mathrm{~d}$ & $1.58 \mathrm{c}$ & $2.08 \mathrm{~b}$ & $3.04 \mathrm{a}$ & $2.29 \mathrm{~b}$ \\
Root/shoot ratio & $0.67 \mathrm{a}$ & $0.40 \mathrm{~b}$ & $0.31 \mathrm{~b}$ & $0.27 \mathrm{c}$ & $0.28 \mathrm{c}$ \\
\hline
\end{tabular}

Mean values followed by the same letter(s) do not differ statistically as per Duncan's Multiple Range Test at $\mathrm{p} \leq 0.05$ 
Table 2. Influence of phosphorus nutrition levels on kenaf plant growth and dry weights of different plant parts

\begin{tabular}{llllll}
\hline \multirow{2}{*}{ Parameters } & \multicolumn{5}{c}{ Phosphorus treatment $(\mathrm{mg} / \mathrm{L})$} \\
\cline { 2 - 6 } & 0 & 25 & 50 & 100 & 200 \\
\hline Diameter, mm & $1.78 \mathrm{~d}$ & $6.86 \mathrm{c}$ & $7.57 \mathrm{~b}$ & $8.42 \mathrm{a}$ & $7.50 \mathrm{~b}$ \\
Plant height, cm & $15.85 \mathrm{c}$ & $38.17 \mathrm{~b}$ & $42.20 \mathrm{a}$ & $43.86 \mathrm{a}$ & $42.18 \mathrm{a}$ \\
Leaf number, plant $^{-1}$ & $3.33 \mathrm{~d}$ & $11.33 \mathrm{c}$ & $12.33 \mathrm{~b}$ & $14.33 \mathrm{a}$ & $12.00 \mathrm{~b}$ \\
Root dry weight, g plant $^{-1}$ & $0.08 \mathrm{c}$ & $0.28 \mathrm{~b}$ & $0.36 \mathrm{~b}$ & $0.63 \mathrm{a}$ & $0.38 \mathrm{~b}$ \\
Stem dry weight, g plant $^{-1}$ & $0.10 \mathrm{c}$ & $0.75 \mathrm{~b}$ & $0.79 \mathrm{~b}$ & $1.43 \mathrm{a}$ & $0.95 \mathrm{~b}$ \\
Leaf dry weight, g plant $^{-1}$ & $0.05 \mathrm{c}$ & $0.44 \mathrm{~b}$ & $0.52 \mathrm{~b}$ & $0.93 \mathrm{a}$ & $0.62 \mathrm{~b}$ \\
Total dry weight, g plant $^{-1}$ & $0.23 \mathrm{c}$ & $1.47 \mathrm{~b}$ & $1.67 \mathrm{~b}$ & $2.99 \mathrm{a}$ & $1.95 \mathrm{~b}$ \\
Root/shoot ratio & $0.53 \mathrm{a}$ & $0.24 \mathrm{~b}$ & $0.27 \mathrm{~b}$ & $0.27 \mathrm{~b}$ & $0.24 \mathrm{~b}$ \\
\hline
\end{tabular}

Mean values followed by the same letter(s) do not differ statistically as per Duncan's Multiple Range Test at $\mathrm{p} \leq 0.0$

Table 3. Influence of potassium nutrition levels on kenaf plant growth and dry weights of different plant parts

\begin{tabular}{llllll}
\hline \multirow{2}{*}{ Parameters } & \multicolumn{5}{c}{ Potassium treatment (mg/L) } \\
\cline { 2 - 6 } & 0 & 25 & 50 & 100 & 200 \\
\hline Diameter, mm & $2.86 \mathrm{~d}$ & $5.08 \mathrm{c}$ & $6.86 \mathrm{ab}$ & $7.48 \mathrm{a}$ & $6.67 \mathrm{~b}$ \\
Plant height, cm & $18.53 \mathrm{~d}$ & $30.46 \mathrm{c}$ & $35.71 \mathrm{~b}$ & $43.83 \mathrm{a}$ & $40.70 \mathrm{a}$ \\
Leaf number, plant $^{-1}$ & $6.33 \mathrm{c}$ & $12.67 \mathrm{~b}$ & $13.67 \mathrm{~b}$ & $15.33 \mathrm{a}$ & $13.77 \mathrm{~b}$ \\
Root dry weight, g plant $^{-1}$ & $0.15 \mathrm{~b}$ & $0.17 \mathrm{~b}$ & $0.43 \mathrm{ab}$ & $0.78 \mathrm{a}$ & $0.74 \mathrm{a}$ \\
Stem dry weight, g plant $^{-1}$ & $0.20 \mathrm{c}$ & $0.55 \mathrm{~b}$ & $0.72 \mathrm{~b}$ & $1.13 \mathrm{a}$ & $0.93 \mathrm{ab}$ \\
Leaf dry weight, g plant $^{-1}$ & $0.14 \mathrm{~d}$ & $0.23 \mathrm{c}$ & $0.65 \mathrm{~b}$ & $1.09 \mathrm{a}$ & $0.90 \mathrm{~b}$ \\
Total dry weight, g plant $^{-1}$ & $0.69 \mathrm{c}$ & $0.95 \mathrm{c}$ & $1.80 \mathrm{~b}$ & $3.00 \mathrm{a}$ & $2.57 \mathrm{~b}$ \\
Root/shoot ratio & $0.44 \mathrm{a}$ & $0.35 \mathrm{~b}$ & $0.31 \mathrm{c}$ & $0.35 \mathrm{~b}$ & $0.40 \mathrm{~b}$ \\
\hline
\end{tabular}

Mean values followed by the same letter(s) do not differ statistically as per Duncan's Multiple Range Test at $\mathrm{p} \leq 0.05$ 


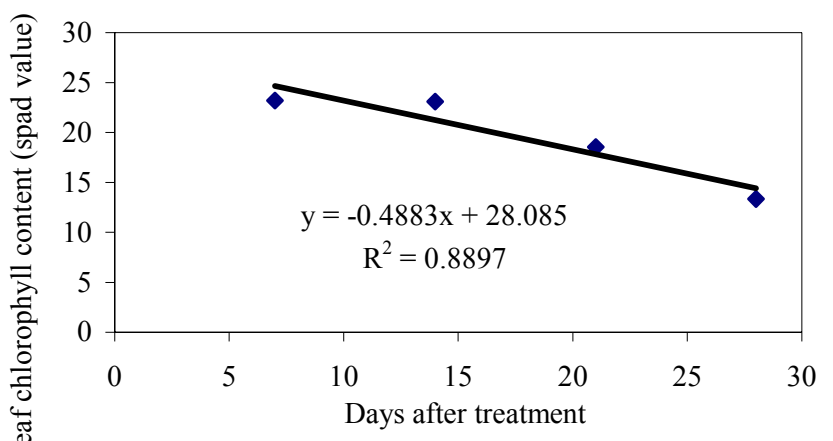

Fig.1. Correlation between kenaf leaf chlorophyll content and 0 levels of nitrogen treatments during the treatment period, 28 days after placement.

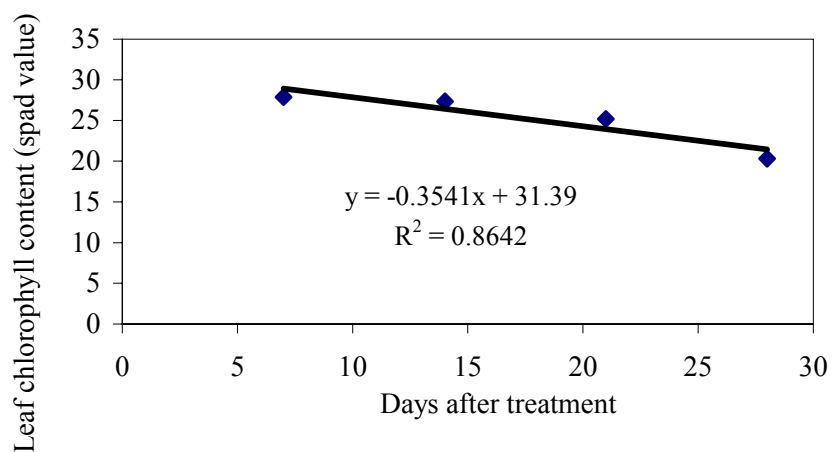

Fig. 2. Correlation between kenaf leaf chlorophyll content and 0 levels of phosphorus treatments during the treatment period, 28 days after placement.

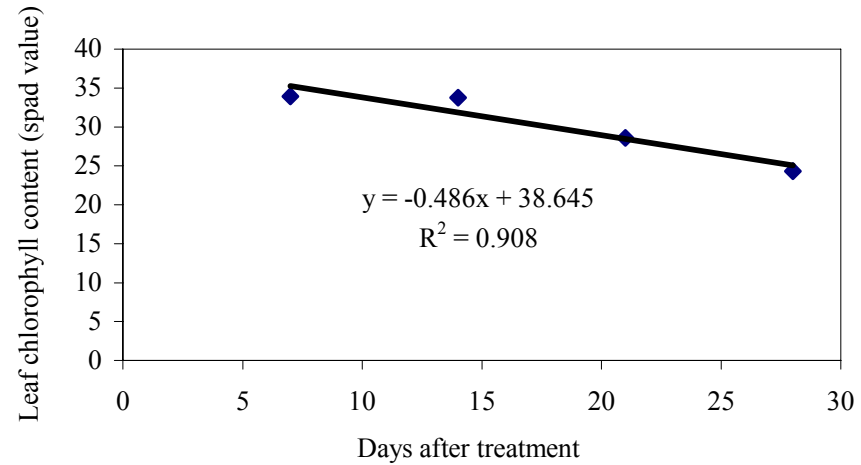

Fig. 3. Correlation between kenaf leaf chlorophyll content and 0 levels of potassium treatments during the treatment period, 28 days after placement. 


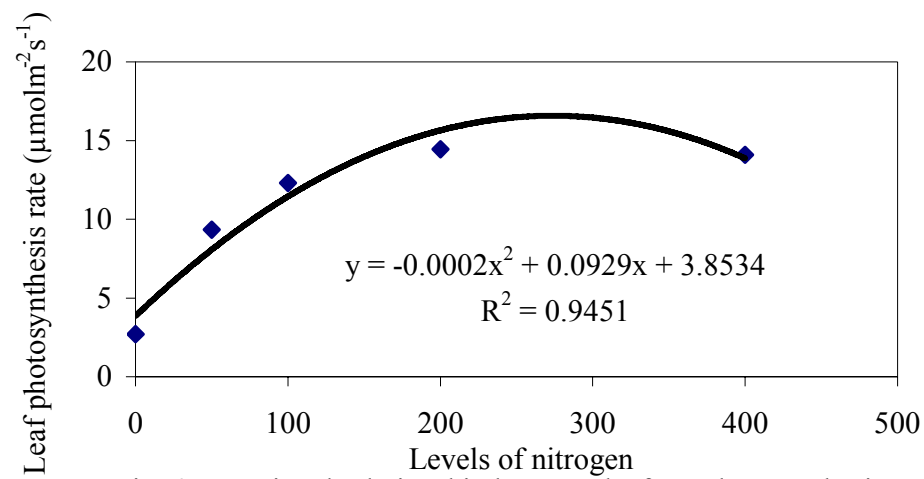

Fig. 4. Functional relationship between leaf net photosynthesis rate at 28 DAT and nitrogen levels

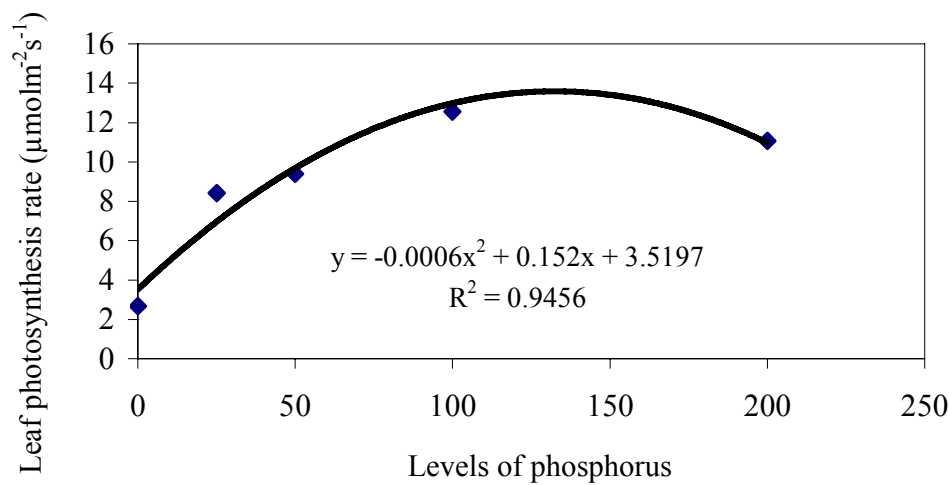

Fig. 5. Functional relationship between leaf net photosynthesis rate at 28 DAT and phosphorus levels

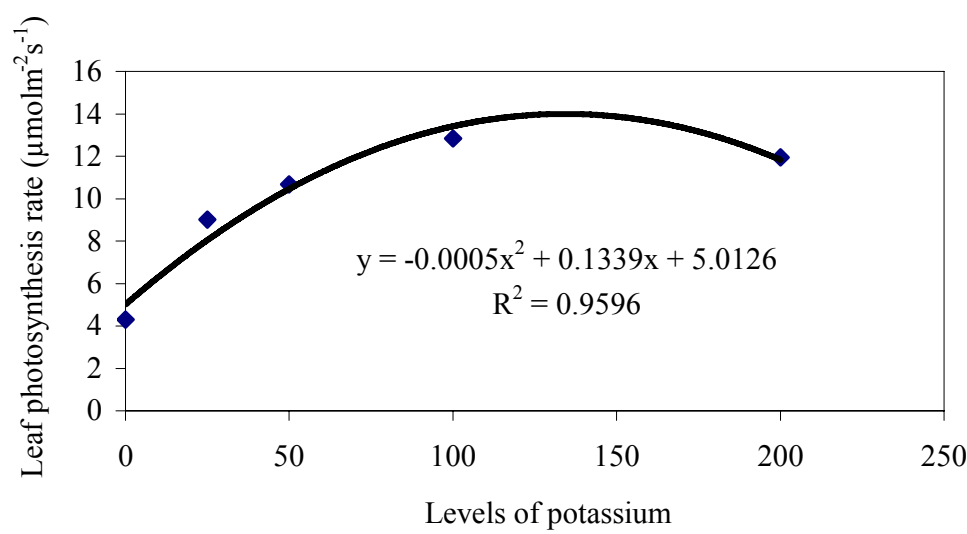

Fig. 6. Functional relationship between leaf net photosynthesis rate at 28 DAT and potassium levels 


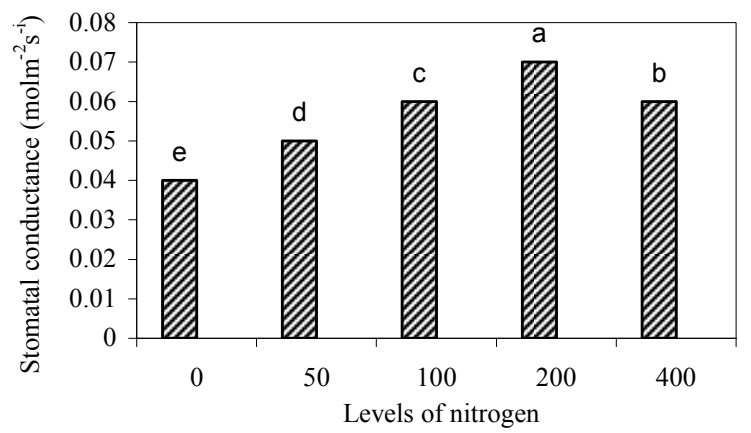

Fig. 7. Influence of levels of nitrogen on stomatal conductance of kenaf plant at 28 DAT

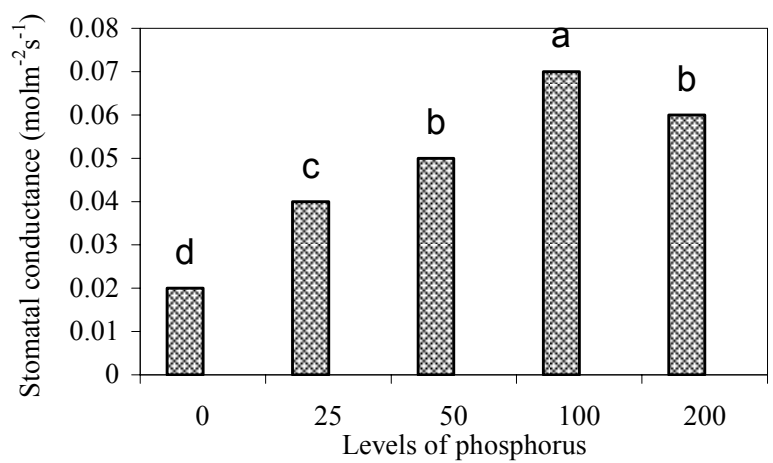

Fig.8. Influence of levels of phosphorus on stomatal conductance of kenaf plant at 28 DAT

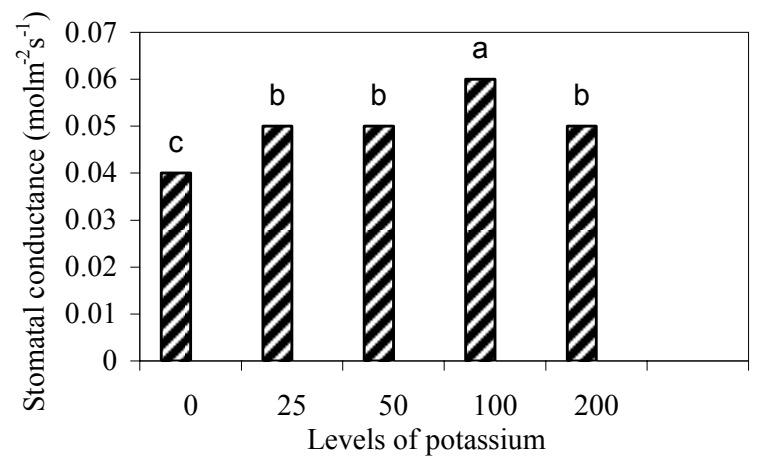

Fig. 9. Influence of levels of potssium on stomatal conductance of kenaf plant at 28 DAT 